\title{
TRPM4 regulates migration of mast cells in mice
}

\author{
Takahiro Shimizu a,c,1, Grzegorz Owsianik ${ }^{\mathrm{a}, 1}$, Marc Freichel ${ }^{\mathrm{b}}$, Veit Flockerzi ${ }^{\mathrm{b}}$, \\ Bernd Nilius $^{\mathrm{a}, *}$, Rudi Vennekens ${ }^{\mathrm{a}}$ \\ a Department of Molecular Cell Biology, Laboratory of Ion Channel Research, KU Leuven, Campus Gasthuisberg, Herestraat 49, bus 802, B-3000 Leuven, Belgium \\ ${ }^{\mathrm{b}}$ Experimentelle und Klinische Pharmakologie und Toxikologie, Universität des Saarlandes, D-66421 Homburg, Germany \\ ${ }^{\mathrm{c}}$ Department of Cell Physiology, National Institute for Physiological Sciences, 444-8585 Okazaki, Japan
}

\section{A R T I C L E I N F O}

\section{Article history:}

Received 10 October 2008

Accepted 18 October 2008

Available online $\mathrm{xxx}$

\section{Keywords:}

TRP channel

TRPM4

Mast cells

Actin cytoskeleton

Antigen

Migration

Transgenic mice

\begin{abstract}
A B S T R A C T
We demonstrate here that the transient receptor potential melastatin subfamily channel, TRPM4, controls migration of bone marrow-derived mast cells (BMMCs), triggered by dinitrophenylated human serum albumin (DNP-HSA) or stem cell factor (SCF). Wild-type BMMCs migrate after stimulation with DNPHSA or SCF whereas both stimuli do not induce migration in BMMCs derived from TRPM4 knockout mice (trpm $4^{-/-}$). Mast cell migration is a $\mathrm{Ca}^{2+}$-dependent process, and TRPM4 likely controls this process by setting the intracellular $\mathrm{Ca}^{2+}$ level upon cell stimulation. Cell migration depends on filamentous actin (F-actin) rearrangement, since pretreatment with cytochalasin $\mathrm{B}$, an inhibitor of $\mathrm{F}$-actin formation, prevented both DNP-HSA- and SCF-induced migration in wild-type BMMC. Immunocytochemical experiments using fluorescence-conjugated phalloidin demonstrate a reduced level of F-actin formation in DNP-HSA-stimulated BMMCs from trpm4 $4^{-/-}$mice. Thus, our results suggest that TRPM4 is critically involved in migration of BMMCs by regulation of $\mathrm{Ca}^{2+}$-dependent actin cytoskeleton rearrangements.
\end{abstract}

(c) 2008 Elsevier Ltd. All rights reserved.

\section{Introduction}

Mast cells have a pivotal role in inflammation reactions, defense against pathogens such as bacteria and virus, and autoimmune diseases [1-3]. They express a number of high-affinity receptor $\left(\mathrm{Fc}_{\varepsilon} \mathrm{RI}\right)$ for immunoglobulin $\mathrm{E}(\mathrm{IgE})$ on their plasma membrane to trigger protective functions in response to multivalent antigens. The cross-linking of antigen to the antigen-specific IgE-coupled receptor causes aggregation of the receptor to initiate multiple signal cascades, followed by cellular activation and release of chemical mediators like histamine and de novo synthesis of pro-inflammatory lipid mediators such as cytokines and chemokines [1]. Mast cells accumulate at local inflammatory tissues. Some reports demonstrated that the migration of mast cells is directed not only by chemotactic factors [4-7] but also by antigens [8]. The molecular mechanism of antigen-induced migration is not yet understood. Nevertheless, it has been shown that sphingosine-1-phosphate (S1P) is one of the important signals in the antigen-induced migration $[9,10]$. In the presence of antigen, IgE-mediated degranulation of mast cells relies on $\mathrm{Ca}^{2+}$ influx through $\mathrm{Ca}^{2+}$ release-activated $\mathrm{Ca}^{2+}$ (CRAC) channels [11,12] and

\footnotetext{
* Corresponding author. Tel.: +32 16345 937; fax: +32 16345991.

E-mail address: bernd.nilius@med.kuleuven.be (B. Nilius).

1 These authors equally contributed to this work.
}

changes of membrane potential, which are modulated by ion channels that control the driving force for $\mathrm{Ca}^{2+}[13,14]$. We have recently demonstrated that in mast cells the transient receptor potential melastatin 4 channel (TRPM4) regulates $\mathrm{Ca}^{2+}$ influx by modulating the membrane potential [14].

In the present study, we examined antigen-triggered migration of sensitized mast cells, and a possible role of TRPM4 in this process. We demonstrate that TRPM4 is directly involved in migration of mast cells in the presence of antigen, likely through controlling the intracellular $\mathrm{Ca}^{2+}$ level upon cell stimulation. Mast cell migration is $\mathrm{Ca}^{2+}$-dependent and possibly relies on TRPM4-dependent induction of filamentous actin (F-actin) formation. Taken together, our results demonstrate that TRPM4 is a regulator of antigen-induced migration of activated mast cells.

\section{Materials and methods}

\subsection{Isolation and sensitization of mast cells}

Bone marrow-derived mast cells (BMMC) were isolated from wild-type and $\mathrm{rrpm}^{-/-}$mice as described in previous papers $[14,15]$. Then BMMC were maintained in Iscove's modified Dulbecco's medium (IMDM; Invitrogen, Carlsbad, CA) supplemented with $10 \%$ heat-inactivated fetal calf serum (FCS), $50 \mu \mathrm{M} \beta$ mercaptoethanol, $10 \mathrm{U} / \mathrm{ml}$ of each penicillin and streptomycin, and $2 \mathrm{ng} / \mathrm{ml}$ recombinant murine IL-3 (R\&D Systems, Minneapolis, MN) 
under a $37^{\circ} \mathrm{C}$ and $5 \% \mathrm{CO}_{2}$ condition. To sensitize BMMC to dinitrophenylated human serum albumin (DNP-HSA; Sigma, St. Louis, MO), BMMC were preincubated overnight with $300 \mathrm{ng} / \mathrm{ml}$ antiDNP-HSA immunoglobulin E (IgE) antibody (Sigma) in IMDM.

\subsection{Migration assays}

BMMC migration was measured in 12-well chemotaxis chambers (Neuro probe, Gaithersburg, MD) using polycarbonate filters with $8 \mu \mathrm{m}$ pore size (Neuro probe). Briefly, sensitized BMMC with the anti-DNP IgE antibody were suspended in RPMI-1640 medium (Invitrogen) without phenol red, supplemented with 1\% FCS after washing them in phosphate buffered saline (PBS) and then placed in the upper wells at density of 60,000 cells/well. The bottom wells were filled with $1 \%$ FCS-containing RPMI medium. Depending on experiments, DNP-HSA was applied into upper and/or bottom wells to stimulate BMMC migration. After the chambers were incubated for $1-3 \mathrm{~h}$ at $37{ }^{\circ} \mathrm{C}$ in $5 \% \mathrm{CO}_{2}$ atmosphere, migrated BMMC into bottom wells were counted by using a hematocytometer. In some experiments, we used K-rich RPMI medium containing $108.7 \mathrm{mM} \mathrm{KCl}, 5.6 \mathrm{mM} \mathrm{Na}_{2} \mathrm{HPO}_{4} \cdot 2 \mathrm{H}_{2} \mathrm{O}, 23.8 \mathrm{mM} \mathrm{NaHCO} 3,0.4 \mathrm{mM}$ $\mathrm{MgSO}_{4} \cdot 7 \mathrm{H}_{2} \mathrm{O}, 0.4 \mathrm{mM} \mathrm{Ca}\left(\mathrm{NO}_{3}\right)_{2} \cdot 4 \mathrm{H}_{2} \mathrm{O}, 11.1 \mathrm{mM}$ D-glucose, and an appropriate amount of RPMI-1640 amino acids solution (Sigma). As a control for K-rich experiments, $103.4 \mathrm{mM} \mathrm{KCl}$ in K-rich solutions was replaced with an equal amount of $\mathrm{NaCl}$. Stem cell factor (SCF; Millipore, Temecura, CA) was used as a chemoattractant. SCFinduced chemotaxis was observed in non-sensitized BMMC. SCF was added into upper and/or bottom wells. After $1.5 \mathrm{~h}$, migrated BMMC were measured in the same way.

In some experiments, BMMC were pretreated with $50 \mu \mathrm{M}$ 1,2-bis-(o-Aminophenoxy)-ethane- $\mathrm{N}, \mathrm{N}, \mathrm{N}^{\prime}, \mathrm{N}^{\prime}$-tetraacetic acid, tetraacetoxymethyl ester (BAPTA-AM) for $20 \mathrm{~min}$ or $10 \mu \mathrm{M}$ cytochalasin B for $15 \mathrm{~min}$. $100 \mu \mathrm{M}$ flufenamate was added in upper wells and $10 \mathrm{mM}$ BAPTA was applied in both wells. To induce cell depolarization by a high $\mathrm{K}^{+}$concentration, $\mathrm{NaCl}$ in the RPMI-1640 medium was replaced by $\mathrm{KCl}$.

\subsection{Actin staining}

To observe rearrangement of globular or filamentous actin, we performed immunohistochemistry using monoclonal mouse anti- $\beta$-actin antibody (Sigma) and staining with the Alexa488conjugated phalloidin probe (Invitrogen). Briefly, sensitized BMMCs were placed on cover glasses coated with poly-L-lysine and stimulated with $1 \mathrm{ng} / \mathrm{ml}$ DNP-HSA for $10 \mathrm{~min}$ at $37^{\circ} \mathrm{C}$ in $5 \%$ $\mathrm{CO}_{2}$ conditions. The cells were fixed with $3.7 \%$ formaldehyde for $10 \mathrm{~min}$, permeabilized with $0.2 \%$ TritonX-100 for $10 \mathrm{~min}$, and blocked with $3 \%$ BSA for $3 \mathrm{~h}$. For $\beta$-actin detection, cells were incubated overnight with anti- $\beta$-actin antibodies and then for $1 \mathrm{~h}$ with Alexa594-conjugated secondary anti-mouse IgG antibodies (triple washing with PBS supplemented with $0.1 \%$ Tween 20 between each step). To visualize F-actin, permeabilized cells were probed with Alexa488-conjugated phalloidin. Images were taken using a confocal microscope imaging system (Zeiss).

\section{4. $\mathrm{Ca}^{2+}$ Imaging}

Cytosolic $\mathrm{Ca}^{2+}$ levels in BMMC were measured with Fura-2, as described before [14].

\subsection{Statistics}

Data are presented as means \pm S.E.M with $n$ denoting the number of cells tested. Statistics were performed using unpaired Student's $t$-test. $p<0.05$ was considered significant.

\section{Results}

\subsection{DNP-HSA has a direct effect on the migration of IgE-specific} antigen sensitized $B M M C$

To study BMMC migration we used a modified Boyden-chamber assay. In this assay, two chambers are placed on top of each other separated by a porous membrane. A population of mast cells is placed in the upper chamber, and migration towards the bottom chamber is monitored. As previously described, sensitized BMMC actively migrate through the membrane toward the bottom chamber in the presence of DNP-HSA in that compartment ([8] and see Fig. 1A). Migration is time- and dose-dependent as shown in Fig. $1 \mathrm{~A}$. In all further experiments we used $1 \mathrm{~h}$ induction with $1 \mathrm{ng} / \mathrm{ml}$ DNP-HSA. The lower concentration was used to avoid massive degranulation of mast cells.

To examine whether the migration of mast cells is due to chemotaxis toward the antigen, we compared the effects when DNP-HSA was only present in the bottom chamber with those when DNP-HSA was present in both reservoirs of the Boyden-chamber. Sensitized BMMC directly stimulated with the antigen also migrated into the bottom reservoir (Fig. 1B). Moreover, a similar level of mast cell migration was observed when the antigen was present in both reservoirs (Fig. 1B). Thus, DNP-HSA directly induced migration of sensitized BMMC cells independently of the antigen gradient.
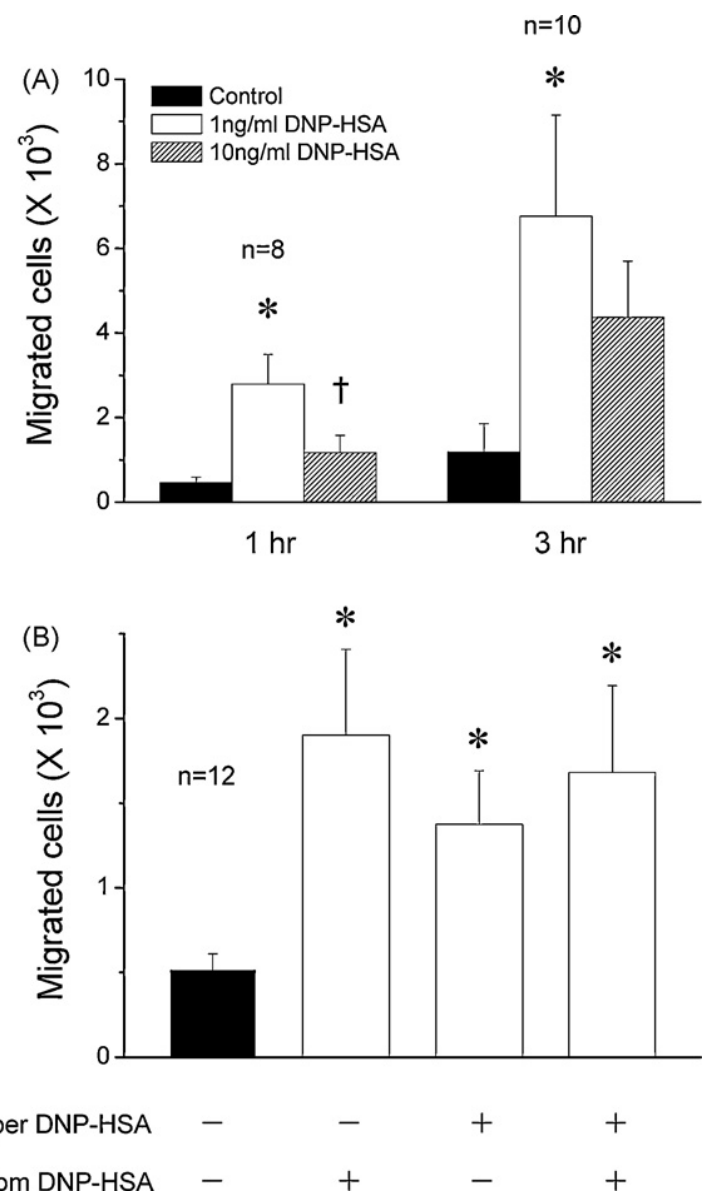

Fig. 1. Antigen induced $B M M C$ migration $(A)$ concentration and time dependence of BMMC migration after stimulation with DNP; (B) DNP-HSA-induced migration was independent of the antigen gradient. DNP-HSA was included at a concentration of $1 \mathrm{ng} / \mathrm{ml}$ into upper well or as indicated in the bottom or in both wells. ${ }^{*} p<0.05$, when compared to non-treated control. $\uparrow p<0.05$, when compared to data in the presence of $1 \mathrm{ng} / \mathrm{ml}$ DNP-HSA. 

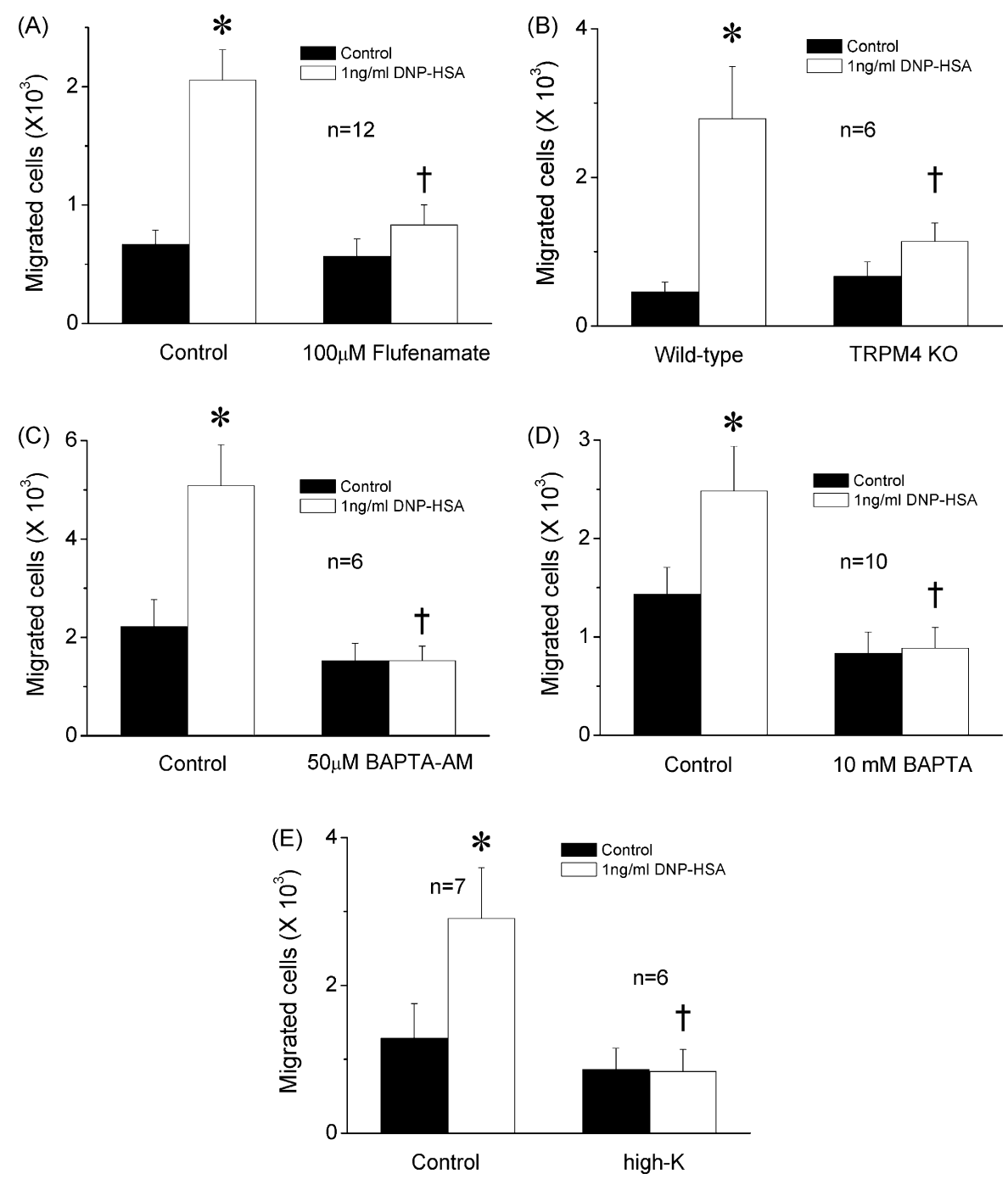

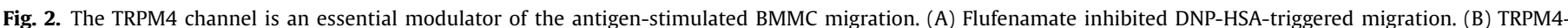

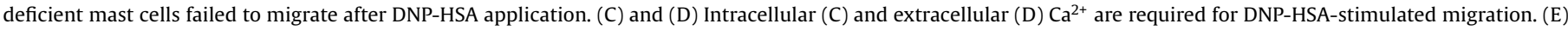

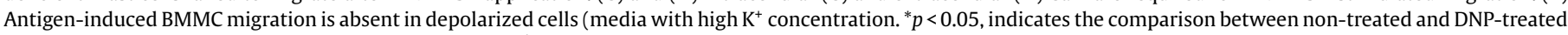
WT cells, $\dagger p<0.05$, between DNP-treated WT and trpm4 ${ }^{-1-}$ cells under various conditions.

\subsection{The lack of TRPM4 activity inhibits antigen-induced BMMC migration}

An application of $100 \mu \mathrm{M}$ flufenamic acid, a potential blocker of TRPM4 [16], in the upper reservoir abolished migration of DNPHSA-stimulated BMMC (Fig. 2A). To determine whether the loss of migration by flufenamic acid was indeed due to the block of TRPM4 channel activity, we performed migration assays with BMMC isolated from trpm4 $4^{-/}$mice. DNP-HSA-stimulated BMMC lacking TRPM4 channels did not display a significant migration independently of DNP-HSA-application in any side of the migration chamber (Fig. 2B, and data not shown).

\section{3. $\mathrm{Ca}^{2+}$ influx is required for antigen-induced BMMC migration}

TRPM4 functions as a $\mathrm{Ca}^{2+}$-activated non-selective cation channel in mast cells, and regulates the intracellular $\mathrm{Ca}^{2+}$ level upon mast cell stimulation with DNP [14]. The intracellular $\mathrm{Ca}^{2+}$ concentration $\left(\left[\mathrm{Ca}^{2+}\right]_{i}\right)$ is an important factor for antigen-stimulated migration of BMMC. Indeed, when we loaded mast cells with BAPTA-AM to chelate $\left[\mathrm{Ca}^{2+}\right]_{i}$, application of DNP-HSA did not evoke migration of the cells (Fig. 2C). Similar results were obtained when extracellular $\mathrm{Ca}^{2+}$ was chelated by addition of $10 \mathrm{mM}$ BAPTA into the extracellular medium (Fig. 2D), indicating that $\mathrm{Ca}^{2+}$ influx is essential for antigen-induced migration of mast cells.

Since the membrane potential determines the driving force for $\mathrm{Ca}^{2+}$ influx in mast cells [14], we performed migration assays in medium with a high $\mathrm{K}^{+}$concentration, which prevents membrane hyperpolarization after antigen stimulation. Under high $\mathrm{K}^{+}$conditions, sensitized BMMC failed to migrate even in the presence of DNP-HSA (Fig. 2E). This result confirms that a sufficient driving force for the $\mathrm{Ca}^{2+}$ influx is required to cause antigen-stimulated BMMC migration.

\subsection{TRPM4 function is important for actin cytoskeleton (re)organization}

A dynamic F-actin rearrangement (polymerization/depolymerization) plays a crucial role in cell migration $[17,18]$. Using a fluorescent phalloidin probe, we examined whether the loss of TRPM4 function affects actin cytoskeleton rearrangements in sensitized BMMC. In the absence of DNP-HSA, 
(A)
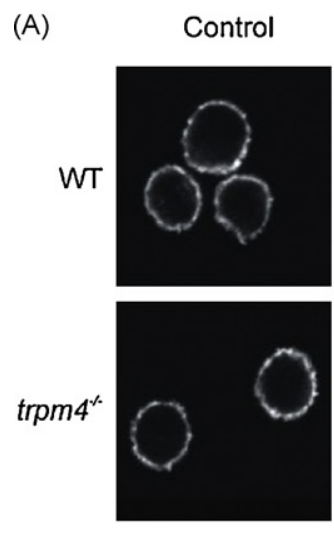

(C)
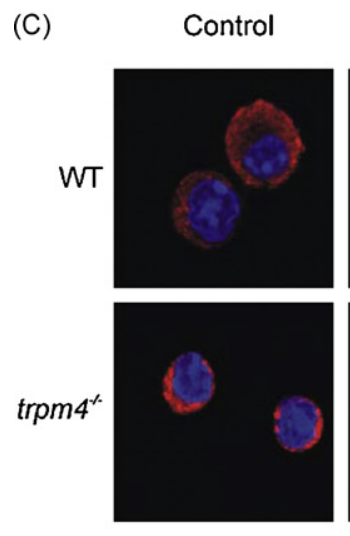

10 min DNP
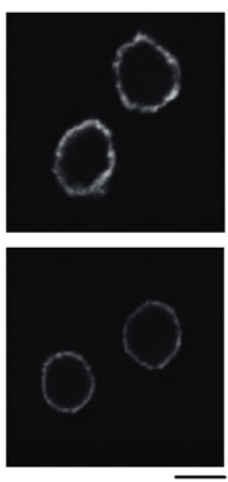

10 min DNP
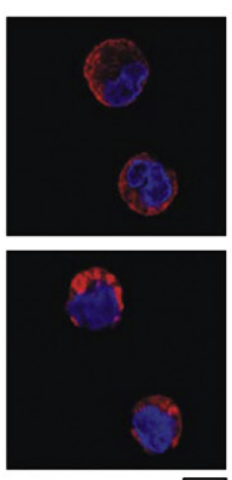
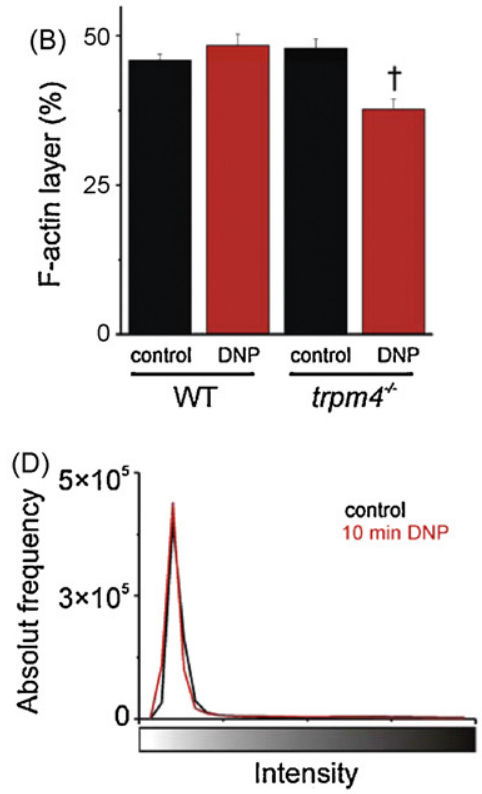

(E)

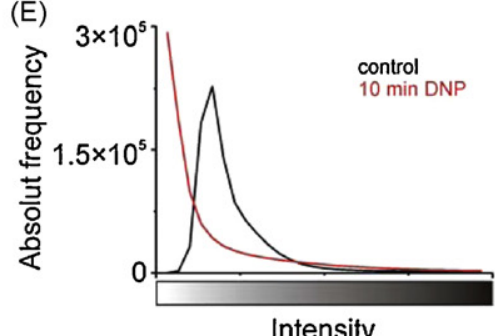

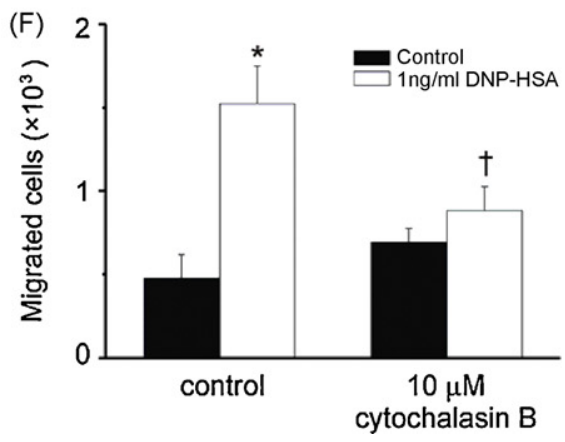

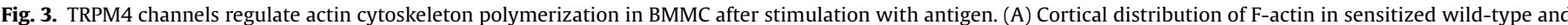

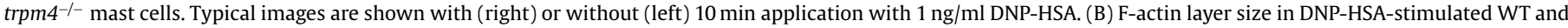

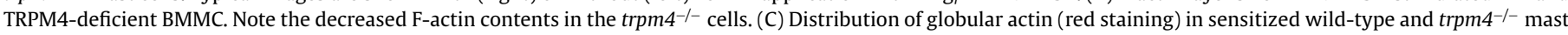

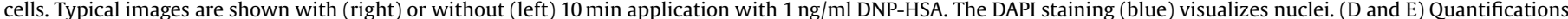

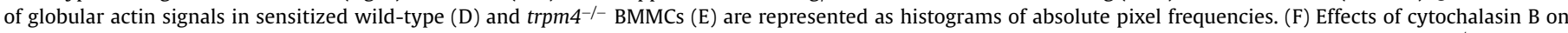

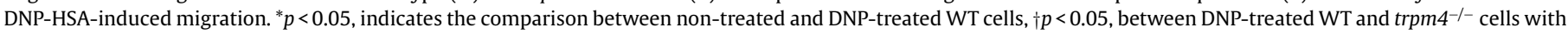
or without cytochalasin $\mathrm{B}$.

wild-type and trpm4-/- BMMC displayed a similar level of F-actin level per cell (Fig. 3A and B). A 10 min application of DNP-HSA to wild-type BMMC induced no change of F-actin pattern when compared to non-stimulated cells. In contrast, trpm $4^{-/-}$BMMC showed significant decrease of F-actin formation ( 20\%) upon stimulation with DNP-HSA (Fig. 3A and B). This observation was related to elevated levels of globular actin in trpm4 $4^{-1-}$ BMMC (Fig. 3C-E).

To confirm the importance of F-actin rearrangements on BMMC migration, we used cytochalasin $\mathrm{B}$, an inhibitor of F-actin polymerization [19]. A 15 min pretreatment with $10 \mu \mathrm{M}$ cytochalasin $B$ resulted in significant decrease of migration of wild-type BMMC after stimulation with DNP-HSA (Fig. 3F).

\subsection{TRPM4 contributes to SCF-induced BMMC migration}

We have shown that antigen stimulation induced a direct effect on BMMC migration, which does not depend on a concentration gradient of the stimulating agent as would be required for chemotaxis. In contrast, stem cell factor (SCF) is a chemotactic factor of mast cell migration $[4,20]$. Application of SCF directly to BMMC cells results in a slow increase of $\left[\mathrm{Ca}^{2+}\right]_{i}$, which is significantly higher in trpm4 $4^{-/-}$compared to WT mast cells (Fig. 4A). Wild-type BMMC displayed concentration-dependent chemotaxis when SCF was applied in bottom reservoir of the Boyden-chamber (Fig. 4B and C). Conversely, trpm4 $4^{-/-}$BMMC showed an impaired chemotaxis 

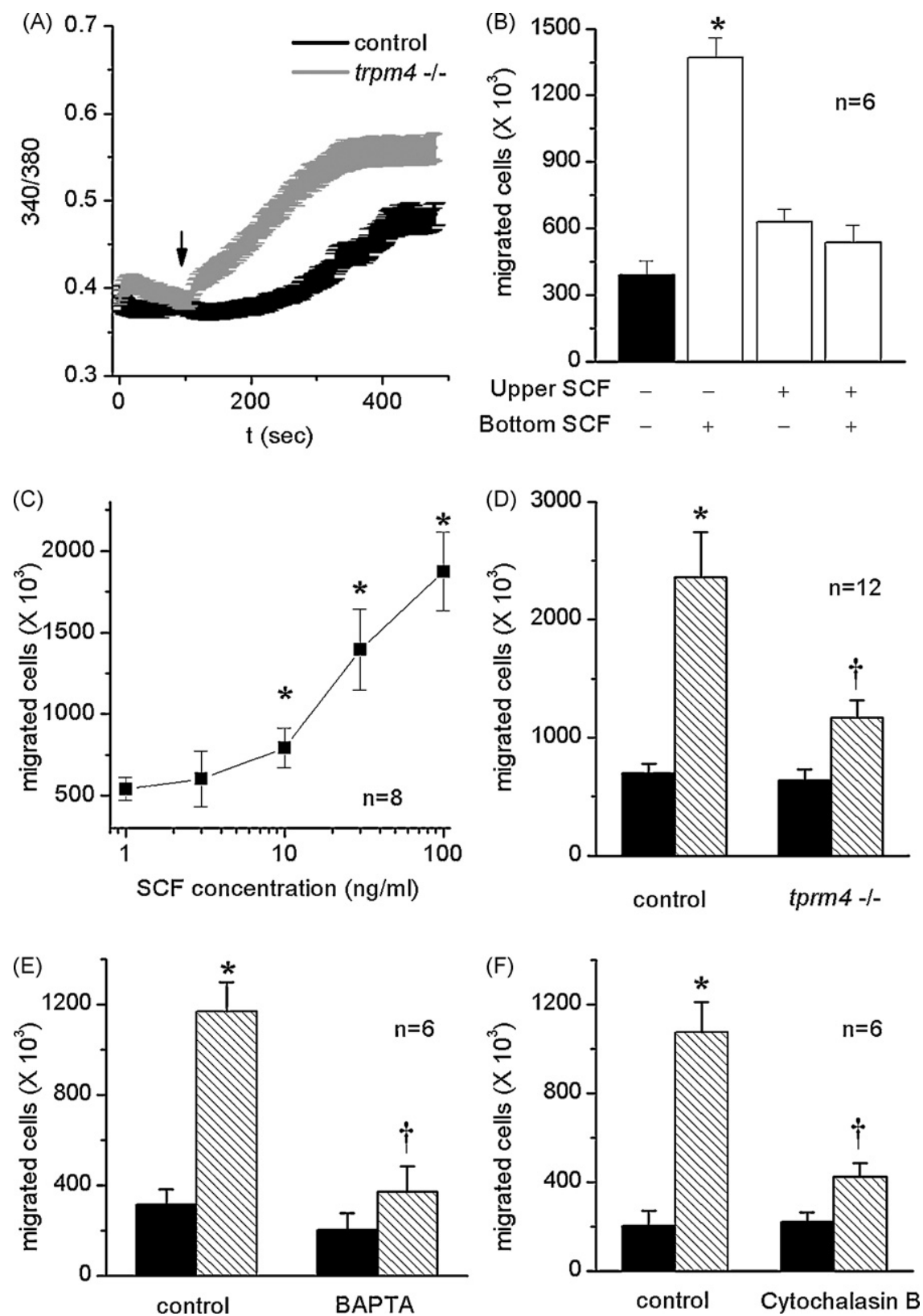

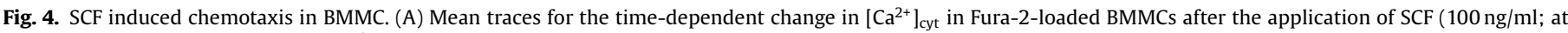

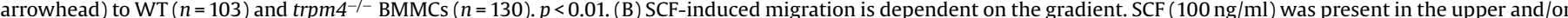

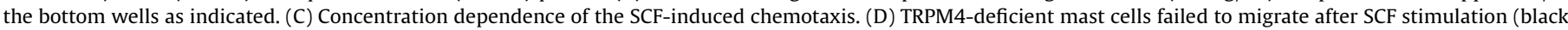

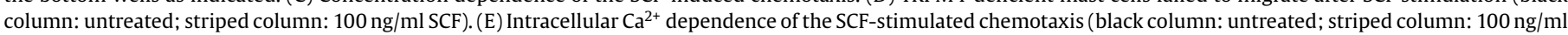

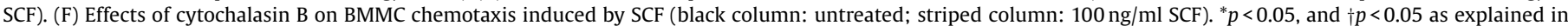
Fig. 2.

triggered by SCF in BMMC (Fig. 4D). Similar inhibiting effects on the chemotaxis towards SCF was caused by application of $100 \mu \mathrm{M}$ flufenamic acid (not shown), by pretreatment with $50 \mu \mathrm{M}$ BAPTA$\mathrm{AM}$ for $20 \mathrm{~min}$ or by $15 \mathrm{~min}$ preincubation with $10 \mu \mathrm{M}$ cytochalasin B (Fig. 4F and G, respectively) These results convincingly show the involvement of TRPM4 in chemotactic migration of non-sensitized BMMC with SCF.

\section{Discussion}

It is generally established that mast cells play a critical and multifaceted role in IgE-dependent hypersensitivity reactions, inflammation and innate immune defense against pathogens. In addition to the production and release of various chemoattractants and pro-inflammatory mediators, mast cells have been shown to increase in numbers (mastocytosis) during inflammatory conditions such as airway hyper-reactivity [21,22], interstitial cystitis [23], and wound healing [24]. In some of these cases, it has been shown that this increase is not due to a proliferation of local mast cells but is, in fact, a product of mast cell recruitment from other body sites. The exact mechanisms by which this recruitment occurs remain unclear [25].

We show here that both antigen-induced migration and SCFmediated chemotaxis are deficient in trpm $4^{-/-}$mast cells. Both processes are highly $\mathrm{Ca}^{2+}$-dependent. When intracellular and extracellular $\mathrm{Ca}^{2+}$ are sequestered, mast cells do not migrate. But 
apparently there also exists an upper $\mathrm{Ca}^{2+}$ level for this process, which is set by TRPM4. We have shown before that in trpm4-1mast cells, antigen stimulation leads to significantly increased $\mathrm{Ca}^{2+}$ influx compared to WT mast cells, due to a lack of control on the driving force for $\mathrm{Ca}^{2+}$ influx, leading to increased degranulation of mast cells and increased cutaneous anaphylaxis response in $\mathrm{KO}$ mice. Furthermore, we now show that also SCF stimulation of mast cells induces a $\mathrm{Ca}^{2+}$ rise, which is significantly higher in $\mathrm{KO}$ compared to WT mast cells. Thus, we hypothesize that intracellular $\mathrm{Ca}^{2+}$ levels in a mast cell must be constrained within a specific concentration window to allow proper migration in an antigenor SCF-directed fashion. Importantly, the lack of migration in our experiments is likely not due to increased degranulation or even cell death because of the very low antigen concentrations used for stimulating migration, and since we observe similar effects between SCF- and DNP-stimulated migration.

The cellular events downstream of intracellular $\mathrm{Ca}^{2+}$ leading to mast cell migration are currently unclear, but involve the actin cytoskeleton. In this context, the rearrangement of actin cytoskeleton is obviously important. Cell migration is critically dependent on actin cytoskeleton dynamics [26]. Our results show indeed that antigen stimulation of sensitized trpm4 ${ }^{-/}$BMMC displayed a significant $(\sim 20 \%)$ decrease in F-actin content. This observation was related to elevated levels of globular actin in trpm4 $4^{-/-}$BMMC. In line with these results pretreatment of sensitized BMMC with cytochalasin $\mathrm{B}$, an actin polymerization inhibitor, resulted in strong impairment of BMMC migration after stimulation with antigen. Previous reports have demonstrated that a rise in cytosolic $\mathrm{Ca}^{2+}$ concentration is associated with actin depolymerization in mast cells $[27,28]$. Further details on the mechanism of this are, however, lacking.

Mast cells derive from pluripotent hemopoietic cells in bone marrow. Partially differentiated, they enter the circulation and complete their differentiation in peripheral tissues. We have shown before that mast cell development and the number of mast cells in in vivo tissue is not different between WT and trpm $4^{-/-}$mast cells [14]. Thus, the above-described migratory defect does not influence mast cell maturation and differentiation.

The trpm $4^{-/-}$mouse is not the first genetic model with a deficient mast cell migration phenotype. Previously, it was shown that mast cells deficient of fyn or syk kinase, several PKC isoforms or the fyn kinase regulatory protein PTP $\alpha$ have similar defects in SCFmediated chemotaxis [29-31]. However, we have previously shown that downstream activity of MAP-kinases (i.e. p38 and Akt) and PLC $\gamma 1$ and $\gamma 2$ upon FceRI is not different between WT and trpm $4^{-/-}$ mice [14]. This indicates that fyn and syk kinase activity is normal in trpm $4^{-1-}$ mast cells, and suggests that the intracellular $\mathrm{Ca}^{2+}$ level is the major malefactor in trpm $4^{-/-}$mast cell migration. It might be tempting to speculate that faulty regulation of PKC isoforms by $\mathrm{Ca}^{2+}$ in trpm $4^{-/-}$mast cells is causing the migration defect [31].

It will be intriguing to check whether migration of other cell types is similarly affected in trpm $4^{-/-}$mice. Interesting in this regard is a recent publication showing an essential role for TRPM4 in migration, but not maturation of dendritic cells, much in the same way as for mast cells [32]. Migration is a somewhat underappreciated aspect of mast cell physiology. However, SCF-mediated mast cell infiltration and activation aggravates inflammation and immunosuppression in a tumor microenvironment and promotes tumor growth [33]. Also, mast cell migration is stimulated by angiogenic factors such as vascular endothelial cell growth factor and platelet-derived growth factor [34]. Thus, it might be interesting to study tumor growth in trpm $4^{-/-}$mice, to assess whether inhibition of mast cell migration could serve as therapeutic strategy for cancer.

\section{Acknowledgement}

We thank all members of the Leuven laboratory for helpful suggestions and criticisms and S. Buchholz and M. Benoit for the help with BMMC culture. This work was supported by grants from the Interuniversity Attraction Poles Programme Belgian State - Belgian Science Policy, P6/28, and the Flemish Government (Excellentiefinanciering EF/95/010), and the Uehara memorial foundation and the Deutsche Forschingsgemeinschaft (MF, VF), Forschungsausschuss Universität des Saarlandes and the HOMFOR program (MF, VF).

\section{References}

[1] D.D. Metcalfe, D. Baram, Y.A. Mekori, Mast cells. Physiol. Rev. 77 (1997) 1033-1079.

[2] Y.A. Mekori, D.D. Metcalfe, Mast cells in innate immunity, Immunol. Rev. 173 (2000) 131-140.

[3] M. Rottem, Y.A. Mekori, Mast cells and autoimmunity, Autoimmun. Rev. 4 (2005) 21-27.

[4] C.J. Meininger, H. Yano, R. Rottapel, A. Bernstein, K.M. Zsebo, B.R. Zetter, The c-kit receptor ligand functions as a mast cell chemoattractant, Blood 79 (1992) 958-963.

[5] S. Mattoli, V. Ackerman, E. Vittori, M. Marini, Mast cell chemotactic activity of RANTES, Biochem. Biophys. Res. Commun. 209 (1995) 316-321.

[6] D. Taub, J. Dastych, N. Inamura, J. Upton, D. Kelvin, D. Metcalfe, J. Oppenheim, Bone marrow-derived murine mast cells migrate, but do not degranulate, in response to chemokines, J. Immunol. 154 (1995) 2393-2402.

[7] G. Nilsson, M. Johnell, C.H. Hammer, H.L. Tiffany, K. Nilsson, D.D. Metcalfe, A Siegbahn, P.M. Murphy, C3a and C5a are chemotaxins for human mast cells and act through distinct receptors via a pertussis toxin-sensitive signal transduction pathway, J. Immunol. 157 (1996) 1693-1698.

[8] T. Ishizuka, F. Okajima, M. Ishiwara, K. Iizuka, I. Ichimonji, T. Kawata, H. Tsukagoshi, K. Dobashi, T. Nakazawa, M. Mori, Sensitized mast cells migrate toward the antigen: a response regulated by p38 mitogen-activated protein kinase and Rho-associated coiled-coil-forming protein kinase, J. Immunol. 167 (2001) 2298-2304.

[9] H. Rosen, E.J. Goetzl, Sphingosine 1-phosphate and its receptors: an autocrine and paracrine network, Nat. Rev. Immunol. 5 (2005) 560-570.

[10] P.S. Jolly, M. Bektas, A. Olivera, C. Gonzalez-Espinosa, R.L. Proia, J. Rivera, S. Milstien, S. Spiegel, Transactivation of sphingosine-1-phosphate receptors by FcepsilonRI triggering is required for normal mast cell degranulation and chemotaxis, J. Exp. Med. 199 (2004) 959-970.

[11] M. Hoth, R. Penner, Depletion of intracellular calcium stores activates a calcium current in mast cells, Nature 355 (1992) 353-356.

[12] T.D. Kim, G.T. Eddlestone, S.F. Mahmoud, J. Kuchtey, C. Fewtrell, Correlating $\mathrm{Ca} 2+$ responses and secretion in individual RBL-2H3 mucosal mast cells, J. Biol. Chem. 272 (1997) 31225-31229.

[13] G. Matthews, E. Neher, R. Penner, Second messenger-activated calcium influx in rat peritoneal mast cells, J. Physiol. 418 (1989) 105-130.

[14] R. Vennekens, J. Olausson, M. Meissner, W. Bloch, I. Mathar, S.E. Philipp, F. Schmitz, P. Weissgerber, B. Nilius, V. Flockerzi, M. Freichel, Increased IgEdependent mast cell activation and anaphylactic responses in mice lacking the calcium-activated nonselective cation channel TRPM4, Nat. Immunol. 8 (2007) 312-320.

[15] M. Laffargue, R. Calvez, P. Finan, A. Trifilieff, M. Barbier, F. Altruda, E. Hirsch, M.P. Wymann, Phosphoinositide 3-kinase gamma is an essential amplifier of mast cell function, Immunity 16 (2002) 441-451.

[16] N.D. Ullrich, T. Voets, J. Prenen, R. Vennekens, K. Talavera, G. Droogmans, B. Nilius, Comparison of functional properties of the Ca2+-activated cation channels TRPM4 and TRPM5 from mice, Cell Calcium 37 (2005) 267-278.

[17] T.D. Pollard, G.G. Borisy, Cellular motility driven by assembly and disassembly of actin filaments, Cell 112 (2003) 453-465.

[18] A. Lambrechts, M. Van Troys, C. Ampe, The actin cytoskeleton in normal and pathological cell motility, Int. J. Biochem. Cell Biol. 36 (2004) 1890-1909.

[19] S. MacLean-Fletcher, T.D. Pollard, Mechanism of action of cytochalasin B on actin, Cell 20 (1980) 329-341.

[20] G. Nilsson, J.H. Butterfield, K. Nilsson, A. Siegbahn, Stem cell factor is a chemotactic factor for human mast cells, J. Immunol. 153 (1994) 3717-3723.

[21] L. Bjermer, L. Rosenhall, T. Angstrom, R. Hallgren, Predictive value of bronchoalveolar lavage cell analysis in sarcoidosis, Thorax 43 (1988) 284-288.

[22] L. Bjermer, A. Engstrom-Laurent, R. Lundgren, L. Rosenhall, R. Hallgren, Bronchoalveolar mastocytosis in farmer's lung is related to the disease activity, Arch. Intern. Med. 148 (1988) 1362-1365.

[23] R. Peeker, L. Enerback, M. Fall, F. Aldenborg, Recruitment, distribution and phenotypes of mast cells in interstitial cystitis, J. Urol. 163 (2000) 1009-1015.

[24] A. Trautmann, A. Toksoy, E. Engelhardt, E.B. Brocker, R. Gillitzer, Mast cel involvement in normal human skin wound healing: expression of monocyte chemoattractant protein-1 is correlated with recruitment of mast cells which synthesize interleukin-4 in vivo, J. Pathol. 190 (2000) 100-106. 
[25] J.B. McLachlan, S.N. Abraham, Studies of the multifaceted mast cell response to bacteria, Curr. Opin. Microbiol. 4 (2001) 260-266.

[26] C. Le Clainche, M.F. Carlier, Regulation of actin assembly associated with protrusion and adhesion in cell migration, Physiol. Rev. 88 (2008) 489-513.

[27] R. Sullivan, M. Burnham, K. Torok, A. Koffer, Calmodulin regulates the disassembly of cortical F-actin in mast cells but is not required for secretion, Cell Calcium 28 (2000) 33-46.

[28] R. Sullivan, L.S. Price, A. Koffer, Rho controls cortical F-actin disassembly in addition to, but independently of, secretion in mast cells, J. Biol. Chem. 274 (1999) 38140-38146.

[29] L.A. Samayawardhena, C.J. Pallen, PTPalpha regulates SCF-dependent c-Kit activation and migration of mast cells, J. Biol. Chem. (2008).

[30] A. Olivera, N. Urtz, K. Mizugishi, Y. Yamashita, A.M. Gilfillan, Y. Furumoto H. Gu, R.L. Proia, T. Baumruker, J. Rivera, IgE-dependent activation of sphingosine kinases 1 and 2 and secretion of sphingosine 1-phosphate requires
Fyn kinase and contributes to mast cell responses, J. Biol. Chem. 281 (2006) 2515-2525.

[31] J. Kitaura, T. Kinoshita, M. Matsumoto, S. Chung, Y. Kawakami, M. Leitges, D. $\mathrm{Wu}, \mathrm{C}$.A. Lowell, T. Kawakami, IgE- and IgE+Ag-mediated mast cell migration in an autocrine/paracrine fashion, Blood 105 (2005) 3222-3229.

[32] G. Barbet, G.M. Demion, I.C. Moura, N. Serafini, T. Leger, F. Vrtovsnik, R.C. Monteiro, R. Guinamard, J.P. Kinet, P. Launay, The calcium-activated nonselective cation channel TRPM4 is essential for the migration but not the maturation of dendritic cells, Nat. Immunol. 9 (2008) 1148-1156.

[33] B. Huang, Z. Lei, G.M. Zhang, D. Li, C. Song, B. Li, Y. Liu, Y. Yuan, J. Unkeless, H. Xiong, Z.H. Feng, SCF-mediated mast cell infiltration and activation exacerbate the inflammation and immunosuppression in tumor microenvironment, Blood 112 (2008) 1269-1279.

[34] B.L. Gruber, M.J. Marchese, R. Kew, Angiogenic factors stimulate mast-cell migration, Blood 86 (1995) 2488-2493. 